\title{
Dichloromethane extract of Potentilla fulgens wall. Ex. Sims ameliorates alloxan- induced oxidative stress and inflammatory responses in mice
}

\author{
Valrielyn Saio ${ }^{1}$, Donkupar Syiem ${ }^{2 *}$ (D), Ramesh Sharma ${ }^{2}$ and Careen Liza Pakyntein ${ }^{2}$
}

\section{Background}

In the pathogenesis of a variety of human diseases including diabetes mellitus, oxidative stress and subsequent oxidative damage to tissues have been involved [1]. Reactive oxygen species (ROS), especially mitochondrial ROS, play a significant causal role in the development and progression of diabetes and its complication $[2,3]$ such as retinopathy, neuropathy, nephropathy, and cardiovascular diseases [4]. Reduction products like superoxide, hydroxyl radical, and hydrogen peroxide are regulated by superoxide dismutase (SOD), catalase (CAT), glutathione peroxidase (GPx), oxidized glutathione reductase systems, vitamin $\mathrm{C}$, and vitamin $\mathrm{E}$ [5]. Hyperglycemia in several ways impairs the endogenous antioxidant defense mechanism [6] and this enhances the vulnerability of tissues to oxidative stress. Under hyperglycemic diabetic conditions, ROS activates nuclear transcription factor NF- $\mathrm{kB}$ [7]. This in turn facilitates the up-regulation of multiple NF- $\mathrm{kB}$ regulated target genes [8] and leads to the negative impact of inflammatory diabetes reactions on the tissue [9]. PPAR- $\gamma$, a nuclear receptor that is also active in the etiology of type II diabetes, also controls NF-kB [10]. It plays an important role in adipogenesis and insulin sensitivity and is triggered by fatty acids [8].

Antioxidant therapy has been widely researched and documented for the alleviation of oxidative stressinduced symptoms in diabetes [11]. According to the World Health Organization (WHO) (2003), by modifying behavior, including food, $90 \%$ of Type II diabetes

\footnotetext{
* Correspondence: dsyiem@yahoo.com

${ }^{2}$ Department of Biochemistry, North-Eastern Hill University, Shillong,

Meghalaya 793022, India

Full list of author information is available at the end of the article
}

can be prevented. High cholesterol, high blood pressure, obesity, and low fruit and vegetable intake combined with diet have been identified as important risk factors that cause diabetes [12]. Hence, there is an increased interest in functional food nutrition and unique bioactive plant components such as flavonoids as phenols as an alternative therapy for the disease. These bioactive compounds can modify cell signaling pathway functions, contribute to inflammatory process modulation, cytoprotective system control, and cell growth control [13, 14].

Potentilla fulgens Wall. ex. Sims of the Rosaceae family is an important medicinal plant of higher Himalaya known for its therapeutic and commercial importance and is known locally by different names in the different regions of higher Himalaya. In the Khasi Hills of Meghalaya, India, P. fulgens Wall. ex. Sims is commonly found at higher altitudes (1500-2000 m MSL) and has been used as a folk remedy by the Khasi people as well as in other parts of the North-Eastern region of India. Traditionally, pieces of roots are chewed along with betel, composed of raw areca nut (Areca catechu), locally called Kwai, and betel leaf (Piper betel). Pharmacologically, roots of $P$. fulgens Wall. ex. Sims has been reported to possess hypoglycemic and anti-hyperglycemic properties in mice [15], affect the polyol pathway in diabetic mice [16] and exhibit gastroprotective and antisecretory effects [17]. We have also reported the antioxidant activity of $P$. fulgens using in-vitro systems and its ameliorative effect on the age-dependent increase in oxidative stress markers in the mouse model $[18,19]$. Jaitak et al. reported the presence of a new bioflavonoid, Potifulgene in the roots of $P$. fulgens along with antioxidant compound epicatechin while the aerial parts 
are reported to contain two new triterpenes, potentene-A, and potentene-B [20]. Thus, the present study was undertaken to investigate the modulatory effect of dichloromethane-methanolic extract of $P$. fulgens (PFDCM) on lipid peroxidation, serum ORAC level, activities of the antioxidant enzymes (CAT, SOD, GPx1) in the liver and kidney of alloxan-induced diabetic mice, to measure the extent of its effect on the activation of NF- $\mathrm{KB}$ in response to an inflammation under the diabetic condition and ultrastructural changes in the liver of diabetic mice. While we have reported the effect of the methanolic extract of $P$. fulgens under a similar diabetic condition in mice [21], this study was designed to explore the therapeutic effect of PFDCM to provide an insight into the mechanistic action of $P$. fulgens as a naturally occurring antioxidant.

\section{Materials and methods}

\section{Chemicals}

All chemicals used were of analytical grade. Alloxan monohydrate ( $\geq 98.0 \%)$, glutathione reduced, 1,1,3,3-tetramethoxy propane (TMOP) ( $\geq 99.0 \%), 5,5$-dithiobis-2-nitrobenzoic acid (DTNB) ( $\geq 99.0 \%)$, 6-hydroxy-2,5,7,8tetramethylchroman-2-carboxylic acid (trolox) ( $\geq 97.0 \%$ ), $\beta$-phycoerythrin, thiobarbituric acid $(\geq 98.0 \%)$, nitrocellulose membrane $\left(0.045 \mu \mathrm{m}\right.$ pore size), $2,2^{\prime}$-azobis (2-aminopropane) dihydrochloride (AAPH) $(\geq 97.0 \%), \mathrm{N}, \mathrm{N}, \mathrm{N}^{\prime} \mathrm{N}$ '-tetramethylenediamine (TEMED) $(\geq 99.0 \%), \quad \beta$ mercaptoethanol $(\geq 99.0 \%)$, sodium azide $(\geq 99.8 \%)$ were procured from Sigma-Aldrich (St. Louis, USA). Primary antibodies for CAT, SOD, GPx1, and $\beta$-actin were purchased from Santa Cruz Biotechnology Inc., USA. Rabbit anti-mouse-IgG HRP conjugate and 3,3',5,5' -tetramethylbenzidine/hydrogen peroxide $\left(\mathrm{TMB} / \mathrm{H}_{2} \mathrm{O}_{2}\right)$ were obtained from Bangalore Genei, India. Ascorbic acid ( $\geq 99.7 \%)$, pyrogallol $(\geq 99.0 \%)$, Diethylenetriaminepentaacetic acid (DETAPAAC) $(\geq 99.0 \%)$, sodium lauryl sulphate $(\geq 99.0 \%)$, bovine serum albumin $(\geq 98.0 \%)$, were purchased from Sisco Research Laboratories. Other chemicals used were of analytical grade obtained from Hi-media and Rankem, India.

\section{Plant material}

P. fulgens was collected from Shillong peak area of Meghalaya (July-August) and the plant specimen (voucher no. 464) was submitted and identified by herbarium curator Dr. P.B. Gurung, Department of Botany, NEHU, Shillong.

\section{Plant extraction}

$800 \mathrm{~g}$ dried root powder of $P$. fulgens was extracted in $2.5 \mathrm{~L}$ dichloromethane-methanol solution $(1: 1)$ for $48 \mathrm{~h}$ by maceration method by stirring at room temperature [22]. The extraction unit was protected from light to prevent polymerization of the secondary metabolites. The mixture was filtered and the filtrate was dried under vacuum in a rotary evaporator (Yamato RE800) yielding $288 \mathrm{~g}(36 \%)$ of PFDCM. The dried mass obtained was used for the investigation.

\section{Experimental animals}

Healthy, male Balb/c Swiss albino mice approximately 6 months of age, weighing $40-45 \mathrm{~g}$ were used for the study. Mice were housed in a room kept under controlled conditions with the temperature maintained at $22{ }^{\circ} \mathrm{C}$ on a 12 -hour light/dark cycle and were fed with balanced mice feed obtained from Amrut Laboratory, Pune, India.

\section{Preparation of diabetic mice}

Animals were administered alloxan monohydrate prepared in acetate buffer $(0.15 \mathrm{M}, \mathrm{pH} 4.5)$ via intraperitoneal (i.p.) route. Before administration, mice were fasted overnight but given water ad libitum. Mice with more than 3-4 fold increased in blood glucose (measured using glucostix; SDCheck) were considered diabetic.

\section{Experimental design}

In this study, mice were divided into 4 groups (comprising six animals each) and treated on alternate days via the i.p. route for 14 days after which mice were starved overnight and sacrificed. Blood serum and tissues were collected and stored for further analysis.

- Group 1 - Normal control (NC), received 2\% of vehicle ethanol.

- Group 2 - Diabetic control (DC), received 2\% of vehicle (ethanol).

- Group 3- Diabetic mice treated with PFDCM extract dissolved in $2 \%$ ethanol $(250 \mathrm{mg} / \mathrm{kg}$ b.w.)

- Group 4- Diabetic mice treated vitamin C dissolved in $2 \%$ ethanol $(250 \mathrm{mg} / \mathrm{kg}$ b.w. $)$

\section{Acute toxicity test}

OECD guidelines [23] were followed for the determination of acute toxicity of P.fulgens. $2000 \mathrm{mg} / \mathrm{kg}$ b.w. of PFDCM was administered intraperitoneally to mice of three age groups (2,6 and 18 months) and upon the death of the animals, the main test was conducted to determine the median lethal dose $\left(\mathrm{LD}_{50}\right)$. The animal is dosed a step below the preliminary dose $(2000 \mathrm{mg} / \mathrm{kg}$ b.w.) and if the animal is moribund or dies, the animal receives a lower dose. The $\mathrm{LD}_{50}$ was estimated to be between the doses of the live and the dead animals.

\section{Lipid peroxidation assay}

For measurement of lipid peroxidation, a $10 \%(\mathrm{w} / \mathrm{v})$ homogenate of the liver and kidney tissues were 
prepared in ice-cold $1.15 \% \mathrm{KCl}$ solution. The homogenates were centrifuged at $1000 \mathrm{~g}$ for $10 \mathrm{~min}$ at $4{ }^{\circ} \mathrm{C}$. The pellet was discarded and the supernatant was used to determine the TBARS levels. Lipid peroxidation was estimated by measurement of thiobarbituric acid-reactive substances (TBARS) [24]. The pink chromogen produced by the reaction of thiobarbituric acid with malondialdehyde (MDA), a secondary product of lipid peroxidation was measured at $\lambda 532 \mathrm{~nm}$. TMOP was used as the standard, and the level of lipid peroxides was expressed as $\mu$ moles of MDA. The assay was repeated for 6 replicates.

\section{Measurement of oxygen radical absorbance capacity (ORAC)}

Blood serum obtained via retro-orbital sinus puncture and was drawn into a sample tube, kept at room temperature for $2 \mathrm{~h}$, and allowed to clot. Following clot formation, tubes were centrifuged at $3000 \mathrm{rpm}$ at $4{ }^{\circ} \mathrm{C}$ for $10 \mathrm{~min}$ to separate the serum. The serum was then treated with $\beta$-phycoerythrin and phosphate buffer $(\mathrm{pH}$ 7.0). ORAC was determined by measuring the inhibition of free radical action on the fluorescent compound, $\beta$ phycoerythrin by the sample [25]. This inhibition can be correlated with the sample's antioxidant capacity. AAPH was used to generate peroxyl radicals. Excitation and emission wavelengths of $\beta$-phycoerythrin were set at $\lambda=$ $562 \mathrm{~nm}$ for excitation and $575 \mathrm{~nm}$ for emission. Trolox was used as the control standard. The antioxidant capacity of the sample was expressed as $\mathrm{mM}$ Trolox equivalents. The assay was repeated for 6 replicates.

\section{Assay of antioxidant enzyme activities}

For estimation of CAT, SOD, and GPx1 activities, tissues were homogenized $(10 \% \mathrm{w} / \mathrm{v})$ in $50 \mathrm{mM}$ potassium phosphate buffer ( $\mathrm{pH} 7.4)$, and centrifuged at $18000 \mathrm{~g}$ for 15 min at $4{ }^{\circ} \mathrm{C}$. The pellet was discarded and the cytosolic supernatant was used as enzyme preparations. The assay was repeated for 6 replicates.

\section{Catalase}

Catalase (CAT) activity was measured according to the method of Aebi [26] by determining the rate of degradation of hydrogen peroxide at $\lambda 240 \mathrm{~nm}$. Phosphate buffer ( $\mathrm{pH}$ 7.0), catalase enzyme, and $\mathrm{H}_{2} \mathrm{O}_{2}$ in a total volume of $3 \mathrm{ml}$ were reacted and absorbance was read at $\lambda 240 \mathrm{~nm}$. The extinction coefficient of $71 \mathrm{mM}^{-1} \mathrm{~cm}^{-1}$ was used for calculation. One unit is defined as $1 \mathrm{mmol}$ of $\mathrm{H}_{2} \mathrm{O}_{2}$ consumed/minute and the specific activity is reported as units $/ \mathrm{mg}$ protein.

\section{Superoxide dismutase}

The activity of superoxide dismutase (SOD) was assayed by the method of Marklund and Marklund [27]. The auto-oxidation of the reaction mixture containing DETAPAAC, pyrogallol, and $\mathrm{H}_{2} \mathrm{O}$ was noted at an interval of $60 \mathrm{~s}$ for $3 \mathrm{~min}$ at $\lambda 470 \mathrm{~nm}$. The auto-oxidation of Tris- $\mathrm{HCl}$ buffer ( $\mathrm{pH}$ 7.4), pyrogallol, homogenate, and $\mathrm{H}_{2} \mathrm{O}$ was noted similarly. The degree of inhibition of autoxidation of pyrogallol, in an alkaline $\mathrm{pH}$ by $\mathrm{SOD}$ was used as a measure of enzyme activity by measuring monitoring the change in absorbance at $\lambda 470 \mathrm{~nm}$. Enzyme activity is defined as the amount of enzyme required for $50 \%$ inhibition of pyrogallol autoxidation /min (units/ mg protein).

\section{Glutathione peroxidase}

Glutathione peroxidase (GPx) was assayed by measuring the amount of reduced glutathione (GSH) at $\lambda 412 \mathrm{~nm}$ according to the method of Rotruck et al [28]. The homogenate, sodium-phosphate buffer ( $\mathrm{pH} 7.0)$, sodium azide, and reduced glutathione were incubated for $3 \mathrm{~min}$ at $37^{\circ} \mathrm{C}$. The reaction was terminated by adding $10 \%$ TCA. This was centrifuged at $1000 \mathrm{~g}$ and the supernatant was reacted with $0.3 \%$ disodium hydrogen phosphate and $0.04 \%$ dithionitro benzoic acid. The absorbance was read at $\lambda 412 \mathrm{~nm}$. The activity of GPx is expressed as $\mu$ moles of GSH utilized $/ \mathrm{min} / \mathrm{mg}$ protein (units/mg protein).

\section{Western blot analysis}

For separation of CAT, SOD, and GPx1 protein, the supernatants obtained by homogenizing the tissues in 50 $\mathrm{mM}$ potassium phosphate buffer ( $\mathrm{pH} 7.4)$, and centrifugating at $18000 \mathrm{~g}$ for $15 \mathrm{~min}$ at $4{ }^{\circ} \mathrm{C}$ were diluted serially in $0.25 \mathrm{M}$ sucrose buffer ( $\mathrm{pH} 7.5)$ and mixed with sample buffer containing $1 \mathrm{M}$ Tris- $\mathrm{HCl}$ (pH 6.8), 1\% bromophenol blue, and glycerol. The sample was incubated for 5 min in a boiling water bath and then loaded into the gel.

Protein levels of CAT, SOD, and GPx1 were detected by Western blot using $12 \%$ sodium dodecyl sulphate polyacrylamide gel electrophoresis (SDS-PAGE) with Laemmli buffer system [29], where an aliquot of sample proteins $(20 \mu \mathrm{L})$ containing $30 \mu \mathrm{g}$ protein for CAT, SOD detection and $50 \mu \mathrm{g}$ protein for GPx1 detection were used. Following electrophoresis, the proteins in the gel were transferred to a nitrocellulose membrane using the Bio-Rad Mini trans-blot electrophoretic unit at $100 \mathrm{~V}$ (constant) for $60 \mathrm{~min}$. The electroblotted membrane was transferred in a blocking solution containing 5\% non-fat dry milk in Tris buffer saline (TBS) for $45 \mathrm{~min}$ at room temperature. After washing in Tween Tris buffer saline (TTBS), the membrane was incubated overnight with primary antibodies for CAT, SOD, and GPx1 or anti- $\beta$ actin antibody solution (1:1000). $\beta$-actin was used as a loading control. The membrane was washed twice in TTBS to remove unbound antibodies and incubated with the secondary antibody, rabbit-anti-mouse-IgG 
conjugated to horseradish peroxidase for proteins detection (1:500) for $3 \mathrm{~h}$ followed by the addition of the substrate $\left(\mathrm{TMB} / \mathrm{H}_{2} \mathrm{O}_{2}\right)$ for color development. The reaction was stopped by washing the membrane in doubledistilled $\mathrm{H}_{2} \mathrm{O}$ and photographed using an HP Scan jet 7400C. The blots were quantified densitometrically using Kodak Digital Science 1D Image Analysis Software, Version 3.0. The analysis was repeated for 6 replicates.

\section{Measurement of NF-KB activation}

Nuclear extracts of liver and kidney tissue homogenates were prepared using the nuclear extraction kit from Cayman chemical company, USA. NF- $\kappa \mathrm{B}$ activation was measured using a DNA-binding ELISA based NF- $\mathrm{kB}$ (p65) transcription factor assay kit from Cayman chemical company, USA. The percentage of DNA binding of NF- $\mathrm{kB}$ (p65) for each sample was calculated as follows-

$$
\% \text { Binding }=\left[\left(\mathrm{Abs}_{\mathrm{sample}}-\mathrm{Abs}_{\mathrm{NSB}}\right) / \mathrm{Abs}_{\mathrm{control}}\right] \times 100
$$

Abs sample is the absorbance of the sample containing the nuclear extracts.

Abs control is the absorbance of the positive control, NF-kB (human p65).

Abs NSB is the absorbance from the non-substrate binding well (without nuclear extracts).

\section{Transmission electron microscopic (TEM) studies}

A section of dissected liver tissues of normal control, diabetic control, and diabetic mice treated with PFDCM extract (6-month old) were examined under the transmission electron microscope (TEM) using JEM-2100 $200 \mathrm{kV}$ JEOL microscope at Sophisticated Analytical Instrumentation Facility (SAIF), NEHU, Shillong. Samples were prepared by following the standard protocol described by Hayat [30] with some modifications. The sections are stained with uranyl acetate for $120 \mathrm{~min}$ at RT, as described by Terzakis [31]. The sections were viewed and photographed at different magnifications ranging from $1000 x$ to $6000 x$.

\section{Statistical analysis}

Values were expressed as mean \pm SEM in each group. Data obtained from 6 different sets were analyzed by one-way analysis of variance (ANOVA) with posthoc Tukey's multiple comparison test (using IBM SPSS Statistics Version 20.0). A $P$ value $<0.05$ was considered significant.

\section{Results}

Acute toxicity test $\left(\mathrm{LD}_{50}\right)$

The LD50 of PFDCM extracts in the three age groups of mice was found to be $750 \mathrm{mg} / \mathrm{kg}$ b.w.

\section{Effect of PFDCM on lipid peroxidation}

A significant increase in TBARS level was seen in the liver, and kidney of the untreated diabetic group compared to the normal group (Fig. 1). TBARS level in the liver was increased by $101 \%(p<0.001)$ and in the kidney by $63 \%(p<0.001)$ above that of the normal group.

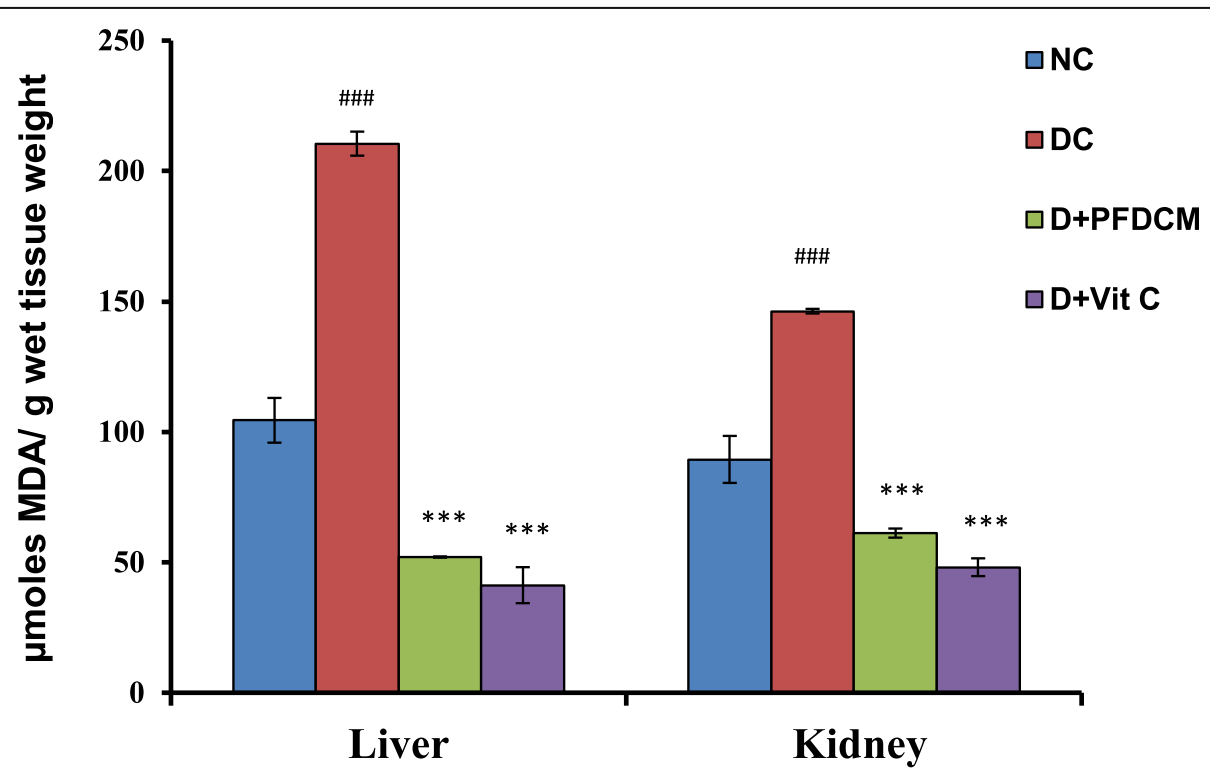

Fig. 1 Effect of PFDCM on lipid peroxidation in liver and kidney of diabetic mice. Means (M) are obtained from 6 separate experiments. SEM ( \pm ): Standard error mean, p: "\#represents the level of significance at ${ }^{\# \# ~} p<0.001$ compared to the normal control group (NC); * ${ }^{*}$ represents the level of significance at ${ }^{* * *} p<0.001$ compared to the diabetic control group (DC) 
PFDCM at $250 \mathrm{mg} / \mathrm{kg}$ b.w. significantly reduced TBARS level by $75 \%(p<0.001)$ in the liver and $58 \%(p<0.001)$ in the kidney from that of the diabetic control. Treatment with vitamin $C$ decreased lipid peroxidation level by $80 \%(p<0.001)$ and $67 \%(p<0.001)$ in the liver and kidney, respectively.

\section{Effect of PFDCM on serum ORAC levels}

The fluorescence intensity of blank, trolox, normal control, diabetic control, and diabetic treated with PFDCM and vitamin $\mathrm{C}$ exponentially declined with time (Fig. 2a). The fluorescence intensity of diabetic control was higher than the normal control and lower than the treated groups. Correspondingly, the ORAC value in the serum of the diabetic control group decreased by $38 \%(p<0.01)$ from that of the normal group (Fig. 2b). Diabetic mice treated with PFDCM exhibited a significant increase by $60 \%(p<0.01)$ in the ORAC value in comparison to the diabetic control, its effect was found to be higher than that shown by vitamin $C$.

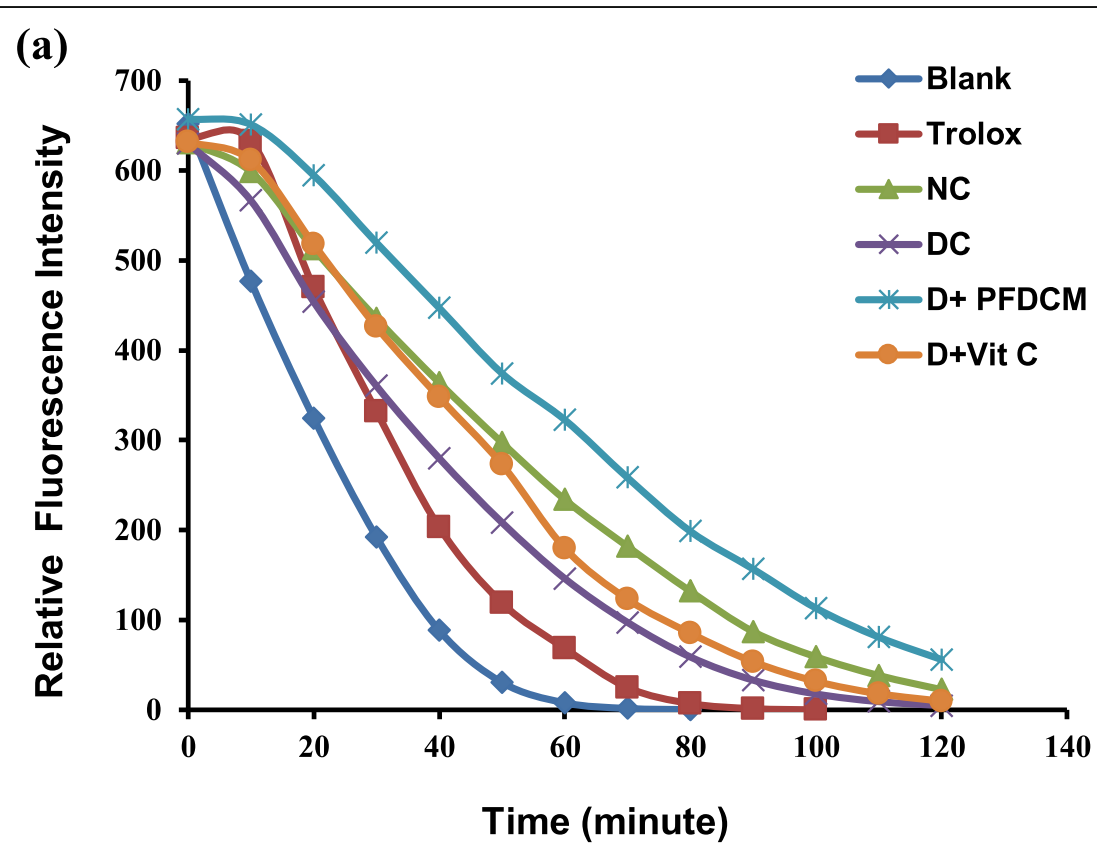

(b)

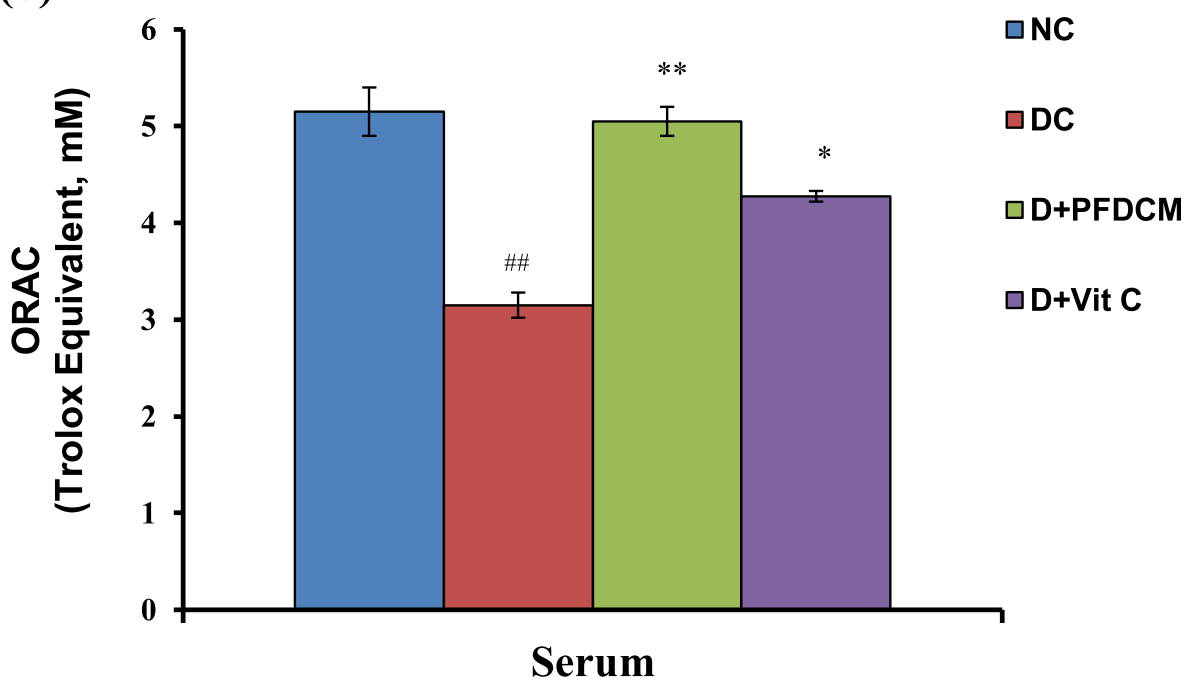

Fig. 2 a Effects of PFDCM on the fluorescence decay of $\beta$-PE induced by AAPH in the serum of diabetic mice. $\mathbf{b}$ Effects of PFDCM on the Oxygen Radical Absorbance Capacity in the serum of diabetic mice. Means (M) are obtained from 6 separate experiments. SEM ( \pm ): Standard error mean, $p$ : ${ }^{*}$ represents the level of significance at ${ }^{\# \#} p<0.01$ compared to the normal control group (NC); ${ }^{*}$ represents the level of significance at ${ }^{*} p<0.05$, ${ }^{* *} p<0.01$ compared to the diabetic control group (DC) 


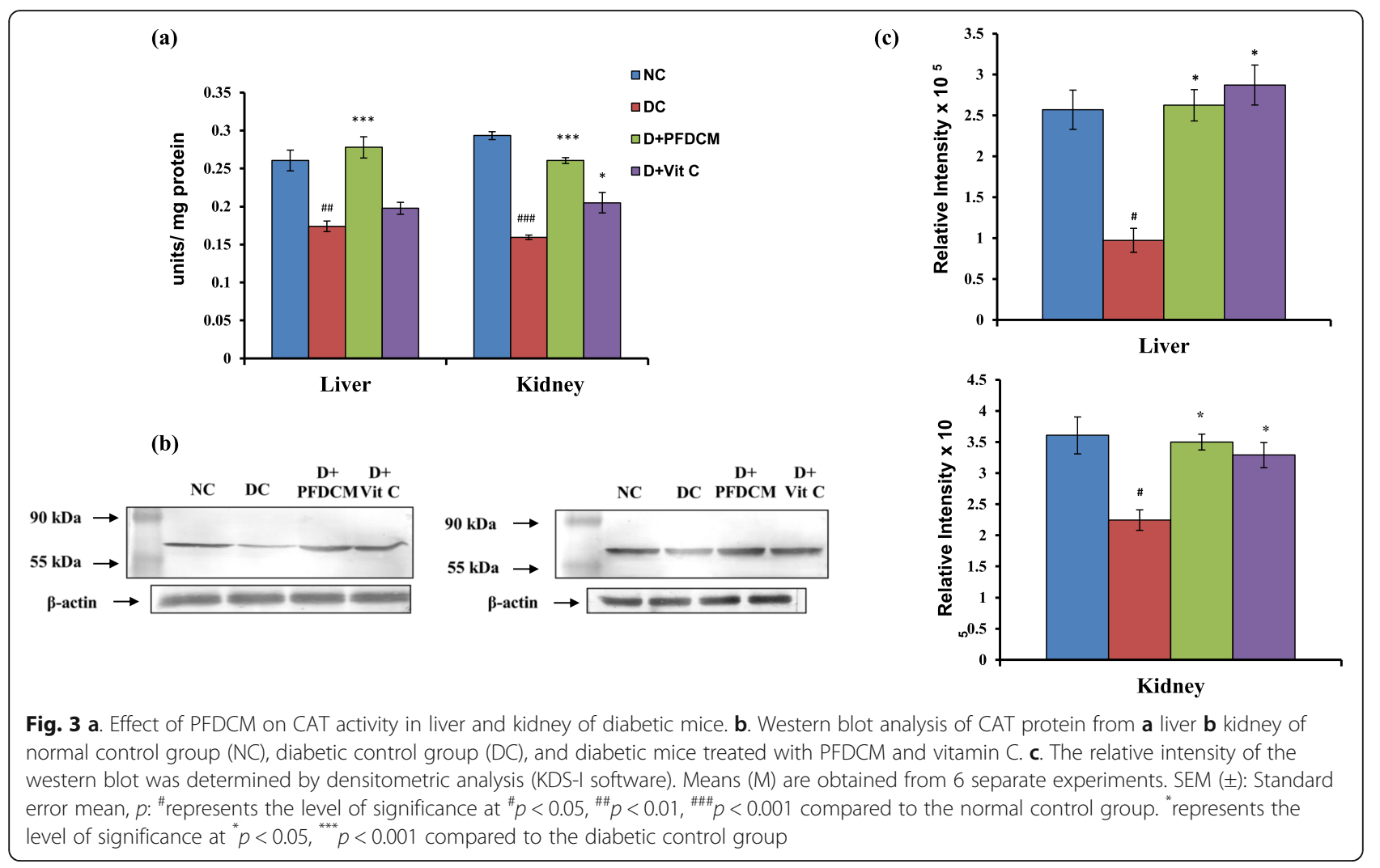

\section{Effect of PFDCM on antioxidant enzymes \\ Catalase}

Alloxan-induced diabetic mice showed a significant decrease in CAT activity in the liver, and kidney when compared to that of the normal group. CAT activity in the liver of diabetic mice decreased by 33\% $(p<0.01)$ and in the kidney by $45 \%(p<0.001)$ (Fig. 3a). Western blot analysis of CAT protein (Fig. 3b) in these tissues confirmed the decreased activity in untreated diabetic mice when compared to the normal group. Diabetic mice treated with PFDCM ( $250 \mathrm{mg} / \mathrm{kg}$ b.w.) exhibited an elevation in the activity of CAT which was found to be $59 \%(\mathrm{p}<0.001)$ and $63 \%(\mathrm{p}<0.001)$ in liver and kidney respectively, from that of the diabetic control. Vitamin $\mathrm{C}$ effect $(250 \mathrm{mg} / \mathrm{kg}$ b.w.) was found to be significant only in the kidney with an increase in CAT activity by $28 \%$ $(p<0.05)$ from that of the diabetic control group. Protein expression levels of CAT were significantly increased after treatment with PFDCM when compared to the untreated diabetic group which corroborated with the significant increase in enzyme activity of PFDCM treated-diabetic mice in the liver.

\section{Superoxide dismutase}

SOD activity in the liver and kidney of diabetic mice was found to significantly decrease when compared to the normal group (Fig. 4a). The reduction was by $18 \%$ ( $p<$
$0.01)$ in the liver and $22 \%(p<0.001)$ in the kidney from that of the normal mice, which was also confirmed by the immunoblot analysis of these diabetic tissues. Treatment with PFDCM resulted in a significant elevation in SOD activity which increased by $20 \%(p<0.05)$ in the liver and $21 \%(p<0.001)$ in the kidney from that of diabetic control. Vitamin C-treated diabetic mice showed a significant increase in SOD activity in the kidney by $18 \%$ $(p<0.01)$ but not in the liver. PFDCM-treated diabetic mice showed an increase in the protein level when compared to diabetic control, which corroborated with increased enzyme activity in this group (Fig. 4b).

\section{Glutathione peroxidase}

A significant decrease in GPx1 activity was observed in the liver and kidney of the untreated diabetic group compared to the normal group (Fig. 5a). GPx1 activity in the liver was reduced by $18 \%(p<0.05)$ and by $30 \%(p<$ 0.05 ) in the kidney from that of the normal group. Treatment with PFDCM extract elevated GPx1 activity in liver and kidney by $41 \%(p<0.01)$, and $51 \%(p<0.05)$, respectively from that of the diabetic control group. Vitamin C significantly increased GPx1 activity in the liver and kidney by $25 \%(p<0.05)$ and $62 \%(p<0.01)$, respectively. In the tested tissues of diabetic mice, protein levels of GPx1 were also found to be lowered in comparison to normal mice. Supplementation with PFDCM 


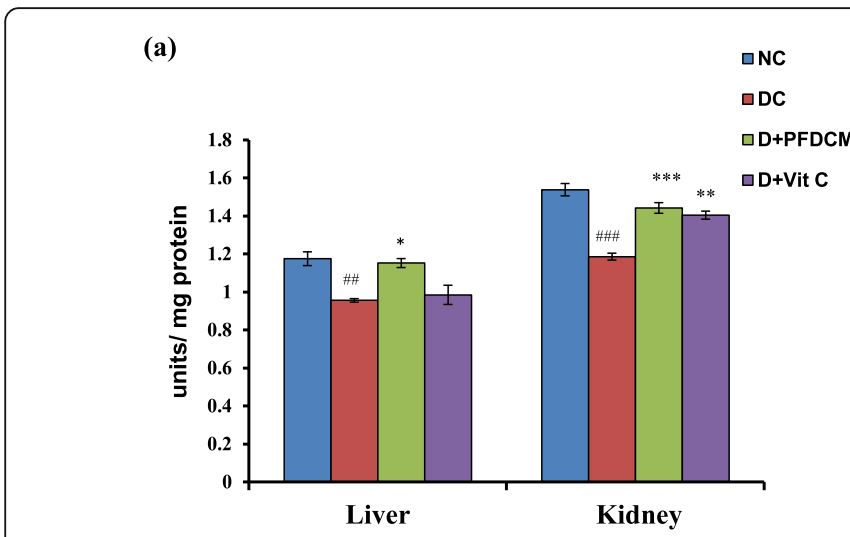

(b)

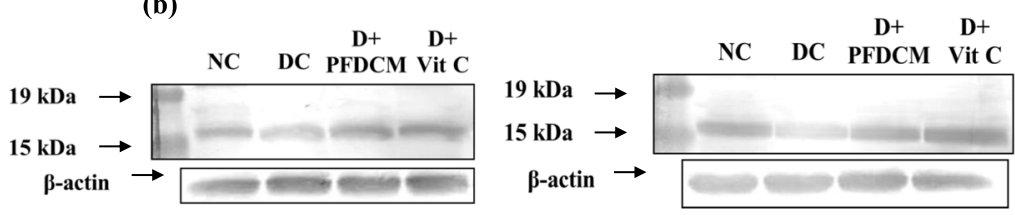

(c)
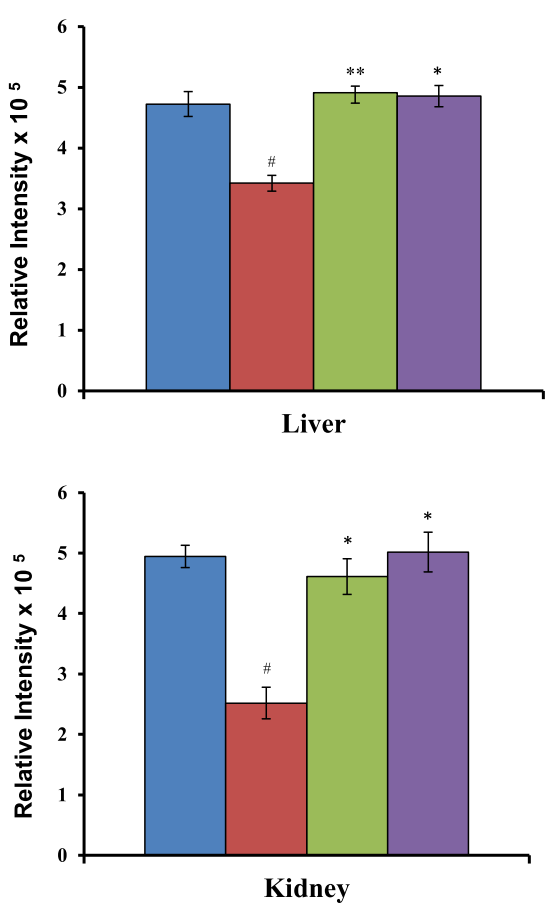

Fig. 4 a. Effect of PFDCM on SOD activity in liver and kidney of diabetic mice. $\mathbf{b}$. Western blot analysis of SOD protein from a liver $\mathbf{b}$ kidney of normal control group (NC), diabetic control group (DC), and diabetic mice treated with PFDCM and vitamin C. $\mathbf{c}$. The relative intensity of the western blot was determined by densitometric analysis (KDS-I software). Means (M) are obtained from 6 separate experiments. SEM ( \pm ): Standard error mean, p: "\#represents the level of significance at ${ }^{\#} p<0.05,{ }^{\# \#} p<0.01,{ }^{\# \# \#} p<0.001$ compared to the normal control group. "represents the level of significance at ${ }^{*} p<0.05,{ }^{* *} p<0.01,{ }^{* * *} p<0.001$ compared to the diabetic control group

considerably increased protein level supporting the finding of increased enzyme activity in these groups (Fig. $5 b)$.

\section{Effect PFDCM on NF-KB activation}

DNA binding activity of NF-kB (p65) was significantly increased in the liver and kidney of diabetic control mice (Fig. 6) where the percentage increase was 64\% $(p<$ $0.001)$ in the liver and $52 \%(p<0.01)$ in the kidney when compared to the normal group. Treatment of diabetic mice with PFDCM considerably reduced the binding activity in liver and kidney by $14 \%(p<0.05)$ and $24 \%(p<$ 0.01 ), respectively from that of the diabetic control. Vitamin C-treated diabetic mice showed a significant reduction in the DNA binding activity which was $24 \%(p<$ $0.01)$ in the liver and $14 \%(p<0.05)$ in the kidney in comparison to that of the diabetic control.

\section{Ultrastructural studies}

Marked differences were observed in the ultrastructural features of the nucleus and mitochondria in the liver of diabetic mice as compared to the normal control mice. Liver tissue of diabetic mice treated with PFDCM extract exhibited lesser structural/morphological changes when compared to the diabetic group. Normoglycemic mice showed normal hepatic cells with a normal euchromatic nucleus (i.e. with normal chromatin distribution) and fewer nuclear heterochromatic contents. The nucleus was more or less centrally placed, having a single prominent nucleolus with surrounding dense cytoplasm in the hepatocytes. The contour of the nucleus shows the nuclear membrane with a regular outline and the absence of any prominent membrane protrusion or invagination (Fig. 7a). The shapes and sizes of the mitochondria were normal and orderly arranged in the form of a round structure without breakage. The mitochondrial membrane (inner and outer) was intact. There was a good alignment of cristae which were arranged in the form of a vertical line, congested and clear. The rough endoplasmic reticulum consisted of closely packed, parallel, and flattened cisternae studded with ribosomes (Fig. 7d). Transmission electron micrographic observation of liver cells in alloxan-induced diabetic mice revealed the presence of distorted nuclei and irregular outlines. The contour of the nucleus was found to be altered and there were some evagination and invagination of the nuclear membrane (Fig. 7b). Some of the mitochondria showed breakage of the outer membrane at places and distortion of the normal round shape of the mitochondria was observed due to the disorganization of the outer membrane. 


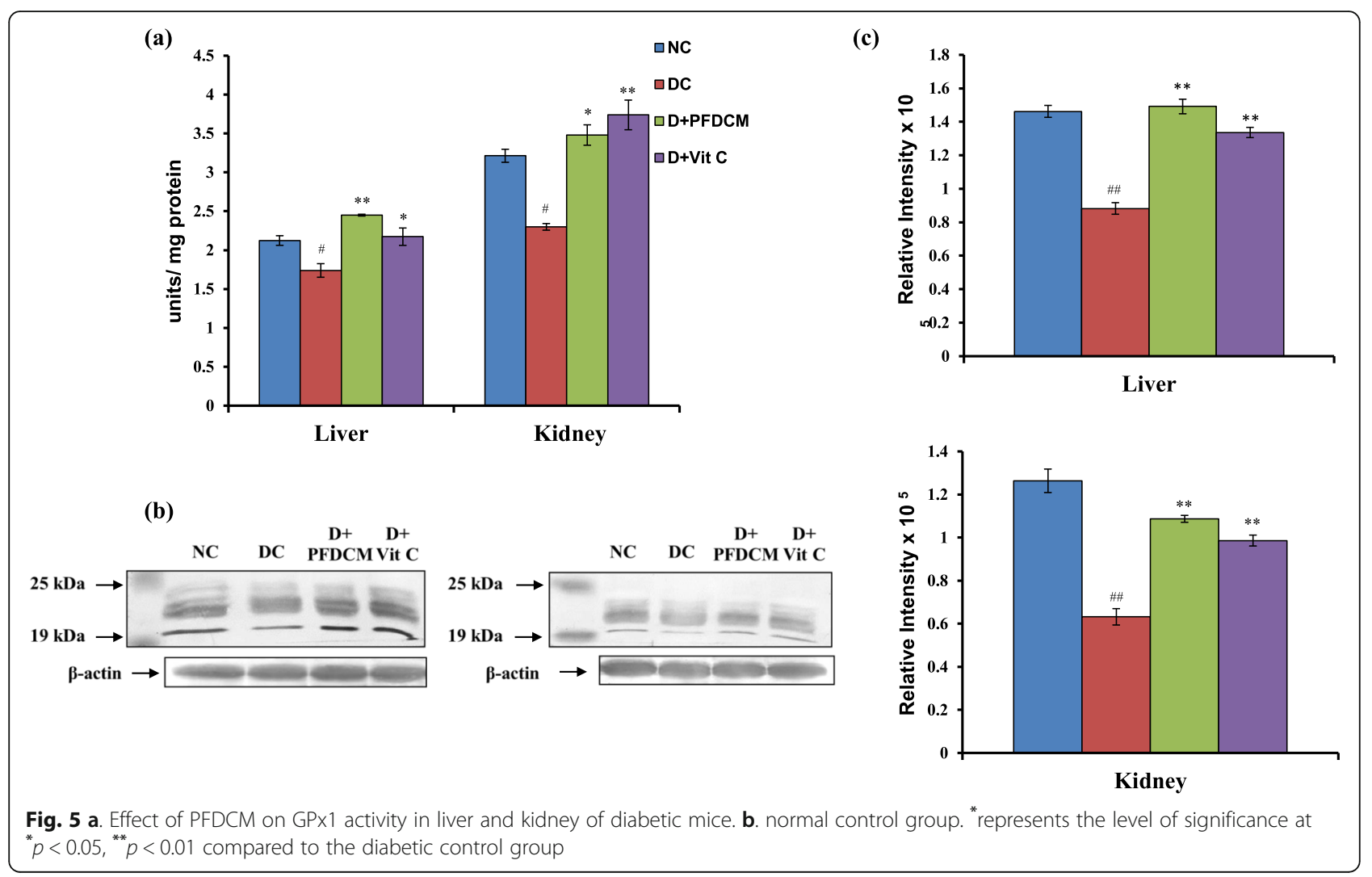

Mitochondria displayed vacuolization and swelling while cristae were less compact. The hepatocytes of diabetic mice showed a poorly defined and fragmented rough endoplasmic reticulum (Fig. 7e). PFDCM extract treatment showed less visible damage in ultrastructural features of the liver sections in diabetic mice with the pronounced normalized appearance of the nucleus as seen in the normal mice (Fig. 7c). Compared to the diabetic liver, the nuclear structure was regular in shape with surrounding denser cytoplasm and any invagination or protrusion was absent. Mitochondrial membranes were intact with no breakage. Cristae were clear, and the rough endoplasmic reticulum appeared well developed with distinct closely packed, parallel, and flattened cisternae studded with ribosomes (Fig. 7f).

\section{Discussion}

Type I and II diabetes is often associated with lipid peroxidation [32]. In alloxan-induced diabetic mice, thiobarbituric acid (TBARS) which is associated with a series of detrimental effects is elevated [33]. This substantial elevation of TBARS implicates oxidative stress. MDA, a major product of lipid peroxidation has been used as a marker of oxidative stress. The extent of peroxidation in diabetes varies from tissue to tissue which may be determined by the presence of a relatively high or low concentration of early peroxidizable fatty acids. Studies on diabetic human subjects revealed a significant elevation of TBARS level in both plasma and erythrocytes [34]. In the present study, the dichloromethane-methanolic extract of $P$. fulgens exerts inhibitory effects on the peroxidation of lipids in the liver and kidney of diabetic mice (Fig. 1). PFDCM at $250 \mathrm{mg} / \mathrm{kg}$ b.w. dosage brought down TBARS level below normal as observed in the normal group which may be attributed to the free radical quenching nature of the extract that is comparable to an equivalent dose of the standard antioxidant, vitamin C. Roots of $P$. fulgens contain substantial amounts of polyphenols including flavonoids [18] which are known to be lipid-soluble and can interact with membrane lipids. These interactions can affect the occurrence and extent of lipid oxidation and membrane disruption by intense free radical production [35]. ROS, as previously mentioned is implicated in many chronic diseases including diabetes but their level must also not be too low given their important biological roles in the body. For constant monitoring and regulating the redox potential in the blood, the levels of ROS can be measured indirectly by measuring the total levels of antioxidants in serum. ORAC assay is one of the tests developed to measure the antioxidant capacities of biological samples from pure compounds such as melatonin, dopamine, and flavonoids to complex matrices such as tea, fruits, vegetables, herbs, and animal tissues [26]. ORAC results showed a decline in the antioxidant levels in serum of diabetic mice when 


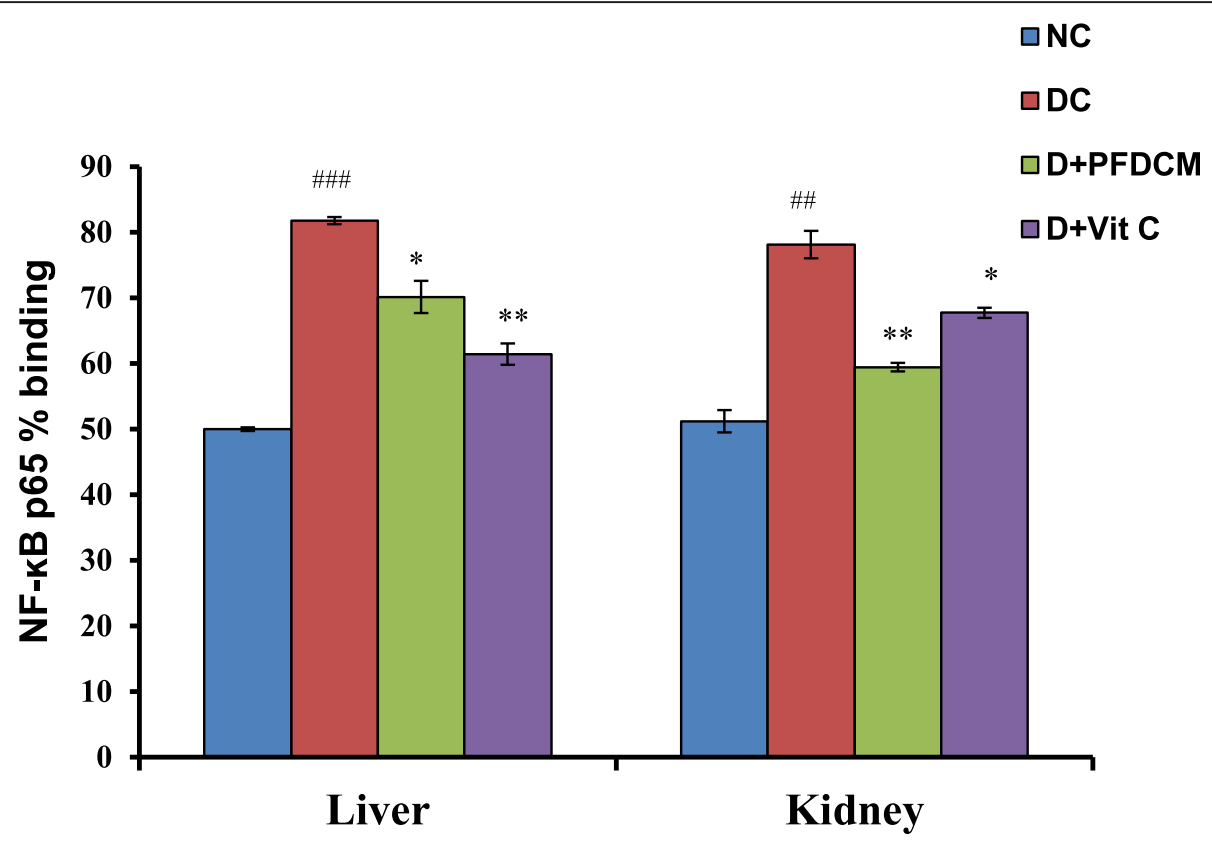

Fig. 6 Effect of PFDCM on the DNA binding activity (\%) of NF-KB (p65) in liver and kidney of diabetic mice. Means (M) are obtained from 6

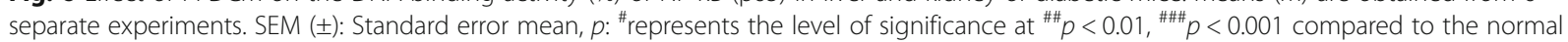
control group (NC); ${ }^{*}$ represents the level of significance at ${ }^{*} p<0.05,{ }^{* *} p<0.01$ compared to the diabetic control group (DC)

compared to the normal mice resulting in the inefficient and incomplete quenching of the free radicals, thereby indicative of a low antioxidant level and/or higher ROS level in the diabetic serum. Administration of the PFDCM extract significantly improved ORAC as compared to the diabetic control followed by vitamin $\mathrm{C}$ modulating the diabetes-induced alterations in the total antioxidant capacity.

Decreased antioxidant enzyme activities observed in this study may be due to nonenzymatic glycosylation of the enzymes [36] and/or inactivation or inhibition of the enzymes by the increased production of alloxangenerated reactive oxygen species (ROS) [37]. The significant elevation of antioxidant enzyme activities in the liver and kidney after treatment with PFDCM may be attributed to the presence of bioactive principles such as flavonoids in the plant which can upregulate these antioxidant defenses in the cell [38]. The increase in protein levels of the enzymes CAT, SOD, and GPx1 after treatment can be related to the increase in their gene expressions by the bioactive constituents in P. fulgens $[39,40]$. As observed in the present study, CAT and SOD protein expression increased upon treatment with vitamin $C$ in a tissue-specific manner as has also been reported by Sadi et al [40].

ROS are associated with the inflammatory response and frequently they contribute to the tissue-damaging effects of inflammatory reactions [41, 42]. There has been substantial evidence, in a range of systems and species, supporting the role of inflammatory processes in the development and progression of diabetes mellitus [43]. Disruption of redox balance in the system leads to an activation of redox-sensitive transcription factors and the subsequent generation of numerous proinflammatory mediators (e.g., cytokines, chemokines, inducible nitric oxide (NO) synthase) [44]. The nuclear transcription factor, NF- $\mathrm{kB}$, implicated in diabetes and its complications is activated by extracellular signals such as those elicited by TNF- $\alpha$ and IL- 1 and its activation induces the expression of genes involved in the control of the immune and inflammatory responses which influence the pathogenesis and progression of the disease [8]. By measuring NF- $\mathrm{kB}$ p65 binding activity on DNA, our results showed that NF- $\mathrm{kB}$ activation increased in tested tissues of diabetic mice indicative of enhanced activation of inflammatory pathways in response to diabetes. Researchers have shown that NF- $\mathrm{KB}$ activation in numerous tissues including adipose, pancreas, and liver contributes to disease pathology observed in patients with type II diabetes [45-49]. As a result, NF- $\mathrm{kB}$ is identified as a promising therapeutic target for new types of treatment to block the inflammatory response in instances where this process becomes chronic or dysregulated [50]. A variety of widely used anti-inflammatory agents, normal or recombinant proteins inhibit the NF$\kappa B$ pathway, at least in part, as one of their targets. Natural products including phytochemicals have been demonstrated to have therapeutic potential in the inhibition 

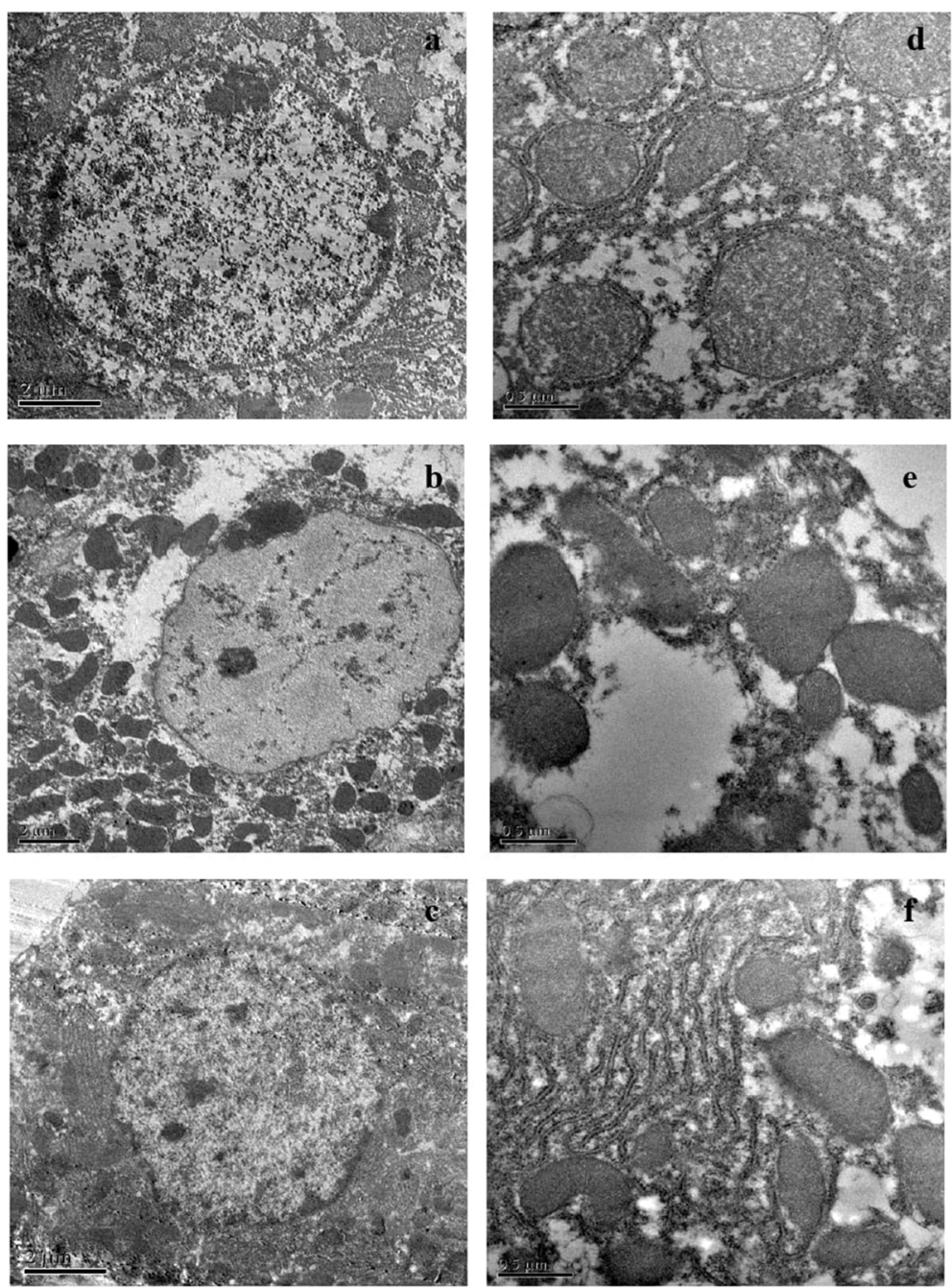

Fig. 7 Transmission electron micrograph showing nucleus (N) in liver of a normal, $\mathbf{b}$ diabetic and c PFDCM extract-treated diabetic mice at 1200x magnification. Transmission electron micrograph showing mitochondria (M) and endoplasmic reticulum (ER) in liver of $\mathbf{d}$ normal, e diabetic, and $f$ PFDCM extract-treated diabetic mice at 6000x magnification

of NF-kB and its pathway for the treatment of inflammatory diseases [51, 52]. Our results clearly showed the ability of the plant extract to modulate NF- $\mathrm{kB}$ activation in diabetes, by its inhibitory effect on the DNA binding activity of NF- $\mathrm{kB}$ p65 subunit following extract administration. Since the activation of the NF- $\mathrm{kB}$ pathway requires many discrete steps involving regulatory proteins that activate signaling pathways leading to its activation, the modulation of the plant extract through its bioactive constituents could have occurred at one or different levels acting on the molecular targets, thereby interrupting the NF- $\kappa B$ pathway [50] as has been similarly suggested that the properties of flavonoids, quercetin, resveratrol, and myricetin may be mediated through the downregulation of the NF- $\mathrm{kB}$ pathway [53-55].

Transmission electron micrographs revealed abnormalities in the architecture of liver tissues of diabetic mice when compared to the normal mice. As shown in this study, the abnormal features of the nucleus in terms of loss of uniform contour, increase in invaginations of the nuclear membrane, development of constriction in the nuclear membrane with heterochromatin condensation and margination, provides enough evidence that alloxan-induced diabetes is likely to cause apoptosis in the liver as reported previously in retinal pericytes [56]. The rough endoplasmic reticulum, predominantly found in hepatocytes where protein synthesis occurs actively, was observed to lose its closely packed network showing degranulation and fragmentation of the rough endoplasmic reticulum (RER). This disorder of RER could be an indication of endoplasmic reticulum stress (ER stress) [57], which is a potential factor for hypoxia, ischemia, and insulin tolerance [50]. A considerable degree of abnormalities was observed in the mitochondrial shape, 
distortion, and breakage of the inner and outer membrane and vacuolization, suggesting impairment of mitochondria in the cell in line with earlier reports $[58,59]$. The disruption of mitochondria is believed to be a key component of apoptosis, and the damaged mitochondria found in this research suggests apoptosis of diabetic mice caused by alloxan in the liver. Since mitochondria play a role fuel in energy production, its disordered function can affect metabolic homeostasis [60]. Complex shifts in mitochondrial morphology have also been found to be consistent with glucose-induced ROS enhancement [61]. This ROS enhancement, in turn, translocates cytosolic $\mathrm{Bcl}$-2-associated $\mathrm{X}(\mathrm{BAX})$ protein to mitochondria and enable BAX to induce the release of cytochrome c [62-64]. Cytochrome c then stimulates caspases leading to apoptotic cell death. Oxidative stress-induced by glucose deprivation triggers BAXassociated events, including subsequent caspase activation and progression of apoptotic cell death [65]. The ultrastructural abnormalities observed in liver tissues of diabetic mice appeared to have been prevented on treatment with PFDCM extract. The possible mechanism underlying the effectiveness of $P$. fulgens extract could be because it contains active components, particularly polyphenolic compounds that contribute to its antioxidant activity. The ability of antioxidants to inhibit the production of ROS and to enhance antioxidant defenses could prevent apoptosis and protect cells from the damaging effect of oxygen radicals $[66,67]$.

\section{Conclusion}

In conclusion, the experiment performed in the present study demonstrated that dichloromethane-methanolic root extract of $P$. fulgens could increase the antioxidant defenses and exhibit protective effects against ultrastructural changes as observed in the liver of diabetic mice; its ability to modulate NF- $\mathrm{KB}$ activation could attenuate inflammatory pathways in response to diabetes. The antioxidant potential of $P$. fulgens offers a promising opportunity for developing an antioxidative agent that can afford protection against the oxidative stress-mediated complications in the pathophysiological condition of diabetes.

\section{Acknowledgements}

We thank Mr. H. Jasha, Department of Chemistry, NEHU for the plant extract preparation; UGC funded UPE program for NEHU, DRS program in Biochemistry, DBT-Twinning project, DST through FIST, and the Department of Biochemistry, North-Eastern Hill University, Shillong, India for providing facilities. We would also like to thank the staff of the TEM instrument, SAIF, $\mathrm{NEHU}$, Shillong, India for their assistance in sample preparation and viewing.

\section{Authors' contributions}

DS and RS designed, conceptualized, and supervised the research. VS performed the experiments. DS, RS, and VS analyzed and interpreted the data of the study. CLP and VS drafted and edited the manuscript. All authors read and approved the final manuscript.
Funding

Not Applicable.

Availability of data and materials

The datasets used and/or analyzed during the current study are available from the corresponding author on reasonable request.

Ethics approval and consent to participate

The study protocol was carried out after approval from the Institutional Ethical Committee (IEC (Animal model)/ NEHU, 09-10-13).

\section{Consent for publication}

Not Applicable.

\section{Competing interests}

The authors declare that they have no competing interests.

\section{Author details}

${ }^{1}$ Ministry of Environment, Forests \& Climate Change, North-Eastern Regional Office, Shillong, Meghalaya 793021, India. ²Department of Biochemistry, North-Eastern Hill University, Shillong, Meghalaya 793022, India.

Received: 5 August 2020 Accepted: 17 December 2020

Published online: 15 January 2021

\section{References}

1. Thannickal VJ, Fanburg BL. Invited review: reactive oxygen species in cell signaling. Am J Physiol Lung Cell Mol Physiol. 2000;279:L1005-28.

2. Nishikawa T, Edelstein D, Du XL, Yamagishi S, Matsumura T, Kaneda Y, et al. Normalizing mitochondrial superoxide production blocks three pathways of hyperglycaemic damage. Nature. 2000;404:787-90.

3. Baynes JW. Role of oxidative stress in development of complications in diabetes. Diabetes. 1991;40(4):405-12

4. Hu D, Jablonski KA, Henderson JA, Magee MF, Welty TK, Robbins DC, et al. Glycemic control in diabetic American Indians. Diabetes Care. 1999;22:1802-

5. Hennekens CH, Gaziano JM. Antioxidants and heart disease: epidemiology and clinical evidence. Clin Cardiol. 1993;16(Suppl 1):110-3.

6. Maritim AC, Sanders RA, Watkins JB 3rd. Diabetes, oxidative stress, and antioxidants: a review. J Biochem Mol Toxicol. 2003;17:24-38.

7. Evans JL, Goldfine ID, Maddux BA, Grodsky GM. Oxidative stress and stressactivated signaling pathways: a unifying hypothesis of type 2 diabetes. Endocr Rev. 2002:23:599-622.

8. Shishodia S, Chaturvedi MM, Aggarwal BB. Role of curcumin in cancer therapy. Curr Probl Cancer. 2007:31:243-305.

9. King GL. The role of inflammatory cytokines in diabetes and its complications. J Periodontol. 2008:79(Suppl 8):1527-34.

10. O'Moore-Sullivan TM, Prins JB. Thiazolidinediones and type 2 diabetes: new drugs for an old disease. Med J Aust. 2002;176:381-6.

11. Matough FA, Budin SB, Hamid ZA, Alwahaibi N, Mohamed J. The role of oxidative stress and antioxidants in diabetic complications. Sultan Qaboos Univ Med J. 2012:12:5-18.

12. Rice-Evans CA, Packer L. Flavonoids in health and disease. 2nd ed. New York: Dekker; 1998.

13. Harborne JB. Nature, distribution and function of plant flavonoids. In: Cody V, Middleton E, Harborne JB, editors. Plant flavonoids in biology and medicine: biochemical, pharmacological and structure activity relationship. Alan R Liss Inc. New York, USA: 1986. p. 15-24.

14. Devasagayam TP, Tilak JC, Boloor KK, Sane KS, Ghaskadbi SS, Lele RD. Free radicals and antioxidants in human health: current status and future prospects. J Assoc Physicians India. 2004;52:794-804.

15. Syiem D, Syngai G, Khup PZ, Khongwir BS, Kharbuli B, Kayang H. Hypoglycemic effects of Potentilla fulgens in normal and alloxan-induced diabetic mice. J Ethnopharmacol. 2002;83:55-61.

16. Syiem D, Majaw S. Effect of different solvent extracts of Potentilla fulgens $L$ on aldose reductase and sorbitol dehydrogenase in normoglycemic and diabetic mice. Pharmacologyonline. 2011;3:63-72.

17. Laloo D, Prasad SK, Krishnamurthy S, Hemalath S. Gastroprotective activity of ethanolic root extract of Potentilla fulgens wall. Ex hook. J Ethnopharmacol. 2013;146:505-14. 
18. Syiem D, Sharma R, Saio V. In vitro study of the antioxidant potential of some traditionally used medicinal plants of north-East India and assessment of their total phenolic content. Pharmacologyonline. 2009;3:952-65.

19. Saio V, Syiem D, Sharma R, Dkhar J. Amelioration of age-dependent increase in oxidative stress markers in male mice by extract of Potentilla fulgens. Redox Rep. 2016;21:130-8.

20. Jaitak V, Kaul VK. Himlata, Kumar N, Singh B, Dhar J, et al. new hopane triterpenes and antioxidant constituents from Potentilla fulgens. Nat Prod Commun. 2010;5:1561-6.

21. Saio V, Syiem D, Sharma R. Effect of Potentilla fulgens on lipid peroxidation and antioxidant status in alloxan-induced diabetic mice. J Basic Clin Pharm. 2012;3:250-4.

22. Sevimli-Gur C, Akgun IH, Deliloglu-Gurhan I, Korkmaz KS, Bedir E. Cytotoxic naphthoquinones from Alkanna cappadocica. J Nat Prod. 2010;73:860-4.

23. OECD. OECD guideline for testing of chemicals. 2001. https://www.oecd. org/chemicalsafety/risk-assessment/1948378.pdf.

24. Ohkawa H, Ohishi N, Yagi K. Assay of lipid peroxides in animal tissues by thiobarbituric acid reaction. Anal Biochem. 1979;95:351-8.

25. Cao G, Prior RL. Comparison of different analytical methods for assessing total antioxidant capacity of human serum. Clin Chem. 1998;44:1309-15.

26. Aebi H. Catalase in vitro. Methods Enzymol. 1984;105:121-6.

27. Marklund SL, Marklund G. Involvement of the superoxide anion radical in the autoxidation of pyrogallol and a convenient assay for superoxide dismutase. Eur J Biochem. 1974;47:469-74.

28. Rotruck JT, Pope AL, Ganther HE. Selenium: biochemical role as a component of glutathione peroxidase. Science. 1973;179:588-90.

29. Laemmli UK. Cleavage of structural proteins during the assembly of the head of bacteriophage T4. Nature. 1970;227:680-5.

30. Hayat MA. In: basic techniques for transmission electron microscopy. 1st ed. USA: Academic Press Inc; 1985

31. Terzakis J. Uranyl acetate, a stain and a fixative. J Ultrastruct Res. 1968;22: 168-84

32. Halliwell B, Gutteridge JMC. In:free radicals in biology and medicine. 3rd ed. London: Oxford University Press; 1998.

33. Smith CM, Marks AD, Lieberman MA. In: Marks' basic medical biochemistry: a clinical approach. 2nd ed. Williams \& Wilkins press: Lippincott; 2005.

34. Aydin A, Orhan H, Sayal A, Ozata M, Sahin G, Isimer A. Oxidative stress and nitric oxide related parameters in type II diabetes mellitus: effects of glycemic control. Clin Biochem. 2001;34:65-70.

35. Verstraeten SV, Fraga CG, Oteiza PI. Flavonoid-membrane interactions: consequences for biological actions. In: Fraga CG, editor. Plant phenolics and human health: biochemistry, nutrition and pharmacology. Wiley: New Jersey; 2010. p. 107-35.

36. Kennedy L, Baynes JW. Non-enzymatic glycosylation and the chronic complications of diabetes: an overview. Diabetologia. 1984;26:93-8.

37. Van Dam PS, Van Asbeck BS, Erkelens W, Marx JJ, Gispen WH, Bravenboer B. The role of oxidation stress in neuropathy and other diabetic complications. Diabetes Metab Rev. 1995;11:181-92.

38. Ibrahim SS. Protective effect of hesperidin, a citrus bioflavonoid, on diabetes-induced brain damage in rats. J Appl Sci Res. 2008;4:84-95.

39. Sadi G, Yılmaz O, Guray T. Effect of vitamin C and lipoic acid on streptozotocin-induced diabetes gene expression: mRNA and protein expressions of Cu-Zn SOD and catalase. Mol Cell Biochem. 2008:309:109-16

40. Sadi G, Güray T. Gene expressions of Mn-SOD and GPX-1 in streptozotocininduced diabetes: effect of antioxidants. Mol Cell Biochem. 2009:327:127-34

41. Pawliczak R. The role of radical oxygen species in airway inflammation. Pol Merkur Lek. 2003;14:493-6.

42. Leiro J, Alvarez E, Arranz JA, Laguna R, Uriarte E, Orallo F. Effects of cisresveratrol on inflammatory murine macrophages: antioxidant activity and down-regulation of inflammatory genes. J Leukoc Biol. 2004;75:1156-65.

43. Tsalamandris S, Antonopoulos AS, Oikonomou E, Papamikroulis GA, Vogiatzi $G$, Papaioannou S, et al. The role of inflammation in diabetes: current concepts and future perspectives. Eur Cardiol. 2019;14:50-9.

44. Aggarwal BB. Nuclear factor-kB: the enemy within. Cancer Cell. 2004;6:203-8.

45. Uysal KT, Wiesbrock SM, Marino MW, Hotamisligil GS. Protecion from obesity-induced insulin resiatance in mice lacking TNF-alpha function. Nature. 1997;389:610-4.

46. Giannoukakis N, Rudert WA, Ghivizzani SC, Gambotto A, Ricordi C, Trucco M, et al. Adenoviral gene transfer of the interleukin-1 receptor antagonist protein to human islets prevents IL1 beta-induced beta-cell impairment and activation of islet cell apoptosis in vitro. Diabetes. 1999;48:1730-6.
47. Xu J, Fu Y, Chen A. Activation of peroxisome proliferator-activated receptor gamma contributes to the inhibitory effects of curcumin on rat hepatic stellate cell growth. Am J Physiol Gastrointest Liver Physiol. 2003;285:G2030 .

48. Alexandraki K, Piperi C, Kalofoutis C, Singh J, Alaveras A, Kalofoutis A. Inflammatory process in type 2 diabetes: the role of cytokines. Ann N Y Acad Sci. 2006:1084:89-117.

49. Tanegashima K, Okamoto S, Nakayama Y, Taya C, Shitara H, Ishii R, et al. CXCL14 deficiency in mice attenuates obesity and inhibits feeding behavior in a novel environment. PLoS One. 2010;5:e10321.

50. Yamamoto Y, Gaynor RB. Therapeutic potential of inhibition of the NF-kB pathway in the treatment of cancer and inflammation. J Clin Invest. 2001; 107:135-42.

51. Piccagli L, Fabbri E, Borgatti M, Bezzerri V, Mancini I, Nicolis E, et al. Docking of molecules identified in bioactive medicinal plants extracts into the p50 NF-kappaB transcription factor: correlation with inhibition of NF-kappaB/ DNA interactions and inhibitory effects on IL-8 gene expression. BMC Struct Biol. 2008;8:38

52. Lee KC, Chang HH, Chung YH, Lee TY. Andrographolide acts as an antiinflammatory agent in LPS-stuimulated RAW264.7 macrophages by inhibiting STAT3-mediated suppression of the NF-kB pathway. J Ethnopharmacol. 2011;135:678-84.

53. Peet GW, Li J. IKappaB kinases alpha and beta show a random sequential kinetic mechanism and are inhibited by staurosporine and quercetin. J Biol Chem. 1999:274:32655-61.

54. Tsai SH, Lin-Shiau SY, Lin JK. Suppression of nitric oxide synthase and the down-regulation of the activation of NF-kB in macrophages by resveratol. $\mathrm{Br}$ J Pharmacol. 1999;126:673-80.

55. Holmes-McNary M, Baldwin AS Jr. Chemopreventive properties of transresveratol are associated with inhibition of IkappaB kinase. Cancer Res. 2000; 60:3477-83.

56. Podesta F, Romeo G, Liu WH, Krajewski S, Reed JC, Gerhardinger C, et al. Bax is increased in the retina of diabetic subjects and is associated with pericyte apoptosis in vivo and in vitro. Am J Pathol. 2000;156:1025-32.

57. Xu C, Bailly-Maitre B, Reed JC. Endoplasmic reticulum stress: cell life and death decisions. J Clin Invest. 2005;115:2656-64.

58. Yang $X$, Borg LA, Eriksson UJ. Altered mitochondrial morphology of rat embryos in diabetic pregnancy. Anat Rec. 1995;241:255-67.

59. Alaraj M, Gajkowska B, Cholewinski M, Lazarewicz JW. Hyperglycaemia and intramitochondrial glycogen granules in the brain of mice. Ultrastructural Stud Folia Neuropathol. 2004:42:113-8.

60. Ra G-P, Boya P, Pauleau AL, Jalil A, Larochette N, Souquere A, et al. The apoptosis/autophagy paradox: autophagic vacuolization before apoptotic death. J Cell Sci. 2005:118:3091-102.

61. Galloway CA, Yoon Y. Mitochondrial dynamics in diabetic cardiomyopathy. Antioxid Redox Signal. 2015:22:1545-62.

62. Ortiz A, Ziyadeh FN, Neilson EG. Expression of apoptosis-regulatory genes in renal proximal tubular epithelial cells exposed to high ambient glucose and in diabetic kidneys. J Investig Med. 1997;45:50-6.

63. Moley KH, Chi MM, Knudson CM, Korsmeyer SJ, Mueckler MM. Hyperglycemia induce apoptosis in pre-implantation embryos through cell death effectory pathways. Nat Med. 1998;4:1421-4.

64. Nakagami H, Morishita R, Yamamoto K, Yoshimura S, Taniyama Y, Aoki M, et al. Phosphorylation of p38 mitogen-activated protein kinase downstream of bax-caspase-3 pathway leads to cell death induced by high D-glucose in human endothelial cells. Diabetes. 2001;50:1472-81.

65. Huppertz B, Frank HG, Reister F, Kingdom J, Korr H, Kaufmann P. Apoptosis cascade progresses during turnover of human trophoblast: analysis of villous cytotrophoblast and syncytial fragments in vitro. Lab Investig. 1999; 79:1687-702.

66. Aoki M, Blazek E, Vogt PK. A role of the kinase mTOR in cellular transformation induced by the oncoproteins P3k and Akt. Proc Natl Acad Sci U S A. 2001;98:136-41.

67. Rossig C, Bollard CM, Nuchtern JG, Merchant DA, Brenner MK. Targeting of $\mathrm{G}$ (D2)-positive tumor cells by human $\mathrm{T}$ lymphocytes engineered to express chimeric T-cell receptor genes. Int J Cancer. 2001;94:228-36.

\section{Publisher's Note}

Springer Nature remains neutral with regard to jurisdictional claims in published maps and institutional affiliations. 